\title{
Records of Plaumanniana trigemmis (Konow) (Hymenoptera: Tenthredinidae) in South America
}

\author{
A. L. Martins ${ }^{a *}$ and D. R. Smith \\ aLaboratório de Biologia Comparada de Hymenoptera, Departamento de Zoologia, Universidade Federal do \\ Paraná - UFPR, Avenida Cel. Francisco Heráclito dos Santos, s/n, Jardim das Américas, \\ CP 19020, CEP 81530-980, Curitiba, PR, Brazil
}

${ }^{b}$ Systematic Entomology Laboratory, Agricultural Research Service, United States Department of Agriculture, c/o National Museum of Natural History, Smithsonian Institution, P.O. Box 37012, MRC 168, Washington, D.C., 20013-7012, USA

*e-mail: andrelmartinsbiol@hotmail.com

Received: January 5, 2016 - Accepted: April 9, 2016 - Distributed: May 31, 2017 (With 3 figures)

Konow (1901) described Stromboceros trigemmis from "Brasilia"; no specific locality was given. Nothing else was published on this species until Malaise (1942) designated it as the type species of his new genus Plaumanniana, thus changing the combination to Plaumanniana trigemmis. Since 1942, nothing else has been published on this species except for inclusion in lists or catalogs (e.g., Taeger et al., 2010). With the collection of a series in Minas Gerais by ALM, the most northern record for the species, and study of additional specimens in collections, we can now give a better picture of its distribution as well as its habitat preference.
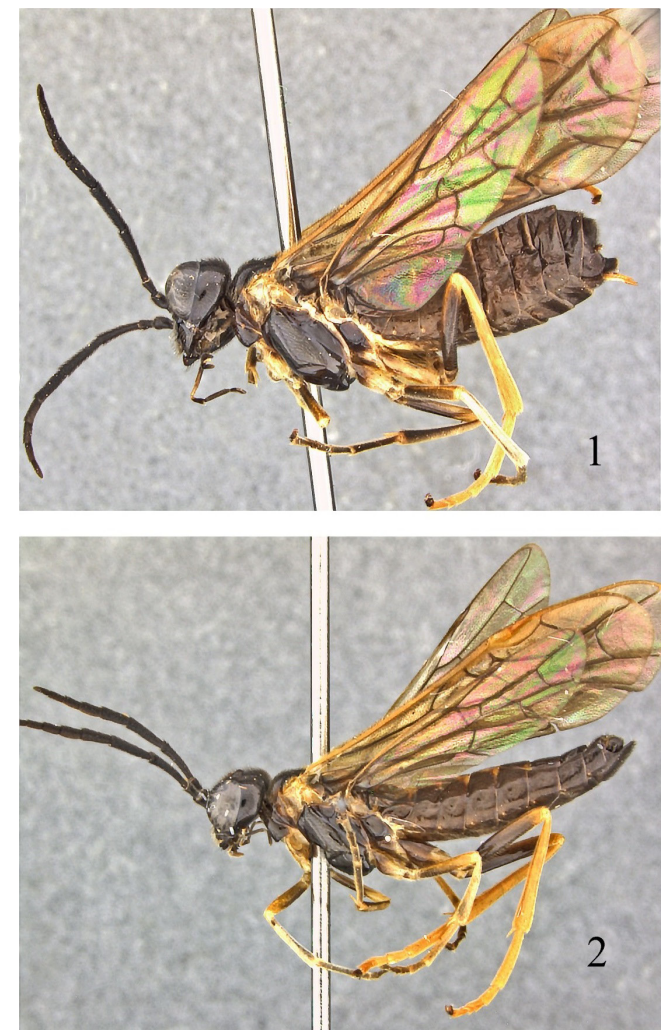

Figures 1, 2. Plaumanniana trigemmis. 1- Female, lateral; 2- Male, lateral.
Plaumanniana can be separated from other genera of Selandriinae in the key by Smith (2007). Plaumanniana trigemmis (Figures 1,2) can be distinguished from the approximately 15 other species of the genus in South America by its black antennae and head, mostly black thorax with the pronotum orange and sometimes the mesoscutellum and margins of the mesoprescutum light orange, mostly black abdomen sometimes with small medial orange spots on the terga, whitish to pale orange legs with most of the femora black, and slightly infuscate wings with the costa and stigma orange and other veins black. The male has not been described, but both sexes are similar in color.

Plaumannia trigemmis is distributed from Minas Gerais south to Santa Catarina in Brazil and Misiones, Argentina. We have examined specimens from the following localities: ARGENTINA: Misiones, Cataratas del Iguazu, 5-9.XI.1979, C. Porter, L. Stange; Iguazu, 4-10 Oct. 1927, RC \& EM Shannon. BRAZIL: Santa Catarina, Nova Teutonia, $27^{\circ} 11^{\prime} \mathrm{B}, 52^{\circ} 23^{\prime} \mathrm{L}, 300-500 \mathrm{~m}$, [many dates in several years], Fritz Plaumann; Petropolis, Rio de Janeiro, 24-27 Oct. 1919; São Bento de Sul, S. Catarina, II.16-18.1969, C. Porter, A. Garcia; Barueri, São Paulo, 22.I.1966, K. Lenko; Pratápolis municipality, Minas Gerais, 22.xii.2014, $20.702^{\circ} \mathrm{S} 46.826^{\circ} \mathrm{W}$, André L. Martins, leg.

The host and habits are unknown. From about 80 specimens examined from different years from Santa Catarina, the species has been collected throughout the year: January (2); February (2); March (16); April (10); May (4); June (9); July (3); August (8); September (10); October (11); November (13); December (2). Thus, there may be continuous generations. Ten males of $P$. trigemmis were collected by ALM, near a creek bed in Minas Gerais using five Moericke traps. The area contained many grasses, ferns, aquatic macrophytes and other plants (Figure 3). A return trip was made to the same site in November 2015 for additional collections, but no specimens were found. Many Selandriinae are associated with ferns, and it could feed on some ferns at the collection site.

Most specimens are deposited in the National Museum of Natural History (USNM), Smithsonian Institution, Washington, D.C., USA. Those collected by ALM are in the collection of the Department of Zoology, Federal University of Paraná (DZUP), Curitiba, PR, Brazil. 


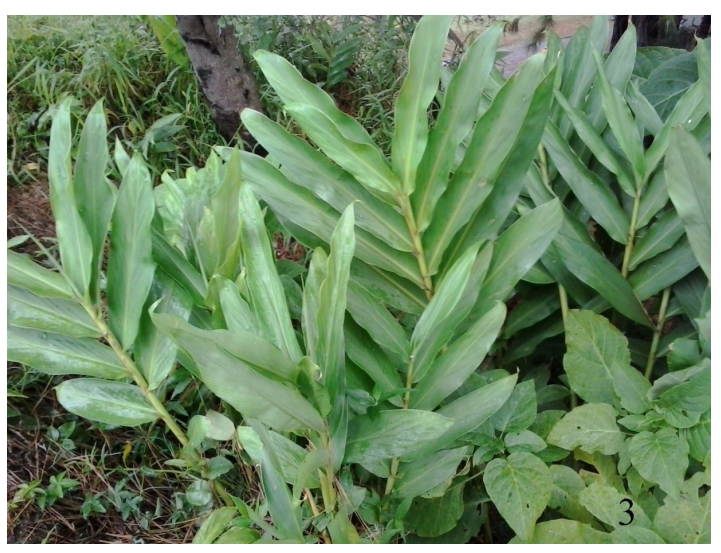

Figure 3. Habitat of collection of Plaumanniana trigemmis, with possible host plants including Hedychium coronarium J. König (Zingiberaceae).

\section{Acknowledgements}

We are very grateful to National Counsel of Technological and Scientific Development of Brazil (CNPq) for the doctoral fellowship provided to A. L. Martins (Proc.: 142415/2015-4).

\section{References}

KONOW, F., 1901. Neuer Chalastogastra-Arten. Természetrajzi Füzetek, vol. 24, pp. 57-72.

MALAISE, R., 1942. New South American sawflies (Hym. Tenthr). Entomologisk Tidskrift, vol. 6, pp. 89-119.

SMITH, D.R., 2007. Familia Tenthredinidae. In: F. FERNÁNDEZ and M.J. SHARKEY, eds. Introducción a los Hymenoptra de la región neotropical. Bogotá: Sociedad Colombia de Entomología, Universidad Nacional de Colombia, pp. 243-252.

TAEGER, A., BLANK, S.M. and LISTON, A.D., 2010. World catalog of Symphyta (Hymenoptera). Zootaxa, vol. 2580, pp. 1-1064. 